\title{
Possible Role of $\gamma$-Irradiated Ginseng in the Modulation of Some Biochemical Disorders Produced by Aluminum in Rats
}

\section{F. Farag and R. G. Hamza}

Food Irradiation Research Dept., National Centre for Radiation Research and Technology (NCRRT), P. O. Box; 29

Nasr City, Egypt.

\begin{abstract}
LUMINUM (Al) toxicity in human and animals has been a matter of concern. Ginseng is liable to be contaminated by micro-organisms during the pre- and post-harvest handlings. Thus, ginseng decontamination by $\gamma$ - rays is needed to warrant the microbiological quality. The aim of this study is to demonstrate the protective effect of $\gamma$-irradiated ginseng against Al-induced toxicity in rat model. Male albino rats were divided into four groups of 8 rats: A control group, the $\gamma$ irradiated ginseng extract (IGE) group; daily received the IGE ( $400 \mathrm{mg} \mathrm{kg}^{-1}$ body wt) for 6 weeks, the $\mathrm{Al}$ group received orally a daily dose $\left(0.5 \mathrm{mg} \mathrm{kg}^{-1}\right.$ body wt) of aluminum chloride $\left(\mathrm{AlCl}_{3}\right)$ for 6 weeks and the irradiated ginseng extract+ $\mathrm{AlCl}_{3}$ (IGE-Al) group, received IGE $\mathrm{AlCl}_{3}$ for 6 weeks. $\mathrm{Al}$ administration significantly decreased some haematological parameters, sex hormones. Antioxidant enzymes activity in liver and testes showed a decrease. The results also showed a significant increase in some hepatic marker enzymes associated with an elevation of tissue lipid peroxidation (LPO). When experimental animals received IGE+ $\mathrm{ALCL}_{3}$, all these parameters were restored to approximately the control levels. These results demonstrated that administration of $\gamma$-irradiated ginseng could be effective in the protection against the toxicity of $\mathrm{AlCl}_{3}$.

Key words: Aluminum, Ginseng, Radiation, Oxidative stress, Antioxidants.
\end{abstract}

The impact of $\mathrm{Al}$ on human health has been increasingly alarming in recent years. The use of AL utensils may increase one's exposure to AL, particularly when used with salty, acidic or alkaline foods (Sharma and Mishra, 2006). Al and its salts are commonly used in daily life, as it was believed to be non-toxic and quickly excreted in the urine. However, this element, in fact, negatively impacts human health (Osinska et al., 2004). It is present in many manufactured foods (Abbasali et al., 2005) and pharmaceutical products (Roberts et al., 2002). 
$\mathrm{Al}$ is potentially toxic to humans. It may be a contributing factor for the development of Alzheimer's disease (Campbell, 2002) and skeletal system disease (Gupta et al., 2005).

There is growing evidence in the literature to use some plant extracts that possess an array of interesting pharmacological effects. Ginseng usually refers to the dried root of several species in the plant genus Panax, which belongs to the Araliacceae family (Xie et al., 2004). The putative bioactive components of Panax ginseng are believed to be a mixture of over 30 heterogeneous glycosidal saponins (glycosylated steroids) known as ginsenosides, which are derivatives of the triterpene dammarane structure (Shao et al., 2004). Ginsenosides are associated with a variety of important pharmacological effects in the human body, including antistress (Kennedy et al., 2003) and antidiabetic (Xie et al., 2004). Ginsenosides have also been demonstrated in both humans and rodents to possess bio-modulating and immunomodulating action, and have produced beneficial effects within the cardiovascular, hematopoietic, endocrine, immune and central nervous systems (Kennedy et al., 2003).

The irradiation of ginseng has been considered as a safe, effective and reliable method for preservation and enhancement of the hygienic quality (Cho et al., 1994). Comparative studies of ginseng subjected to $\gamma$-rays showed negligible changes in physicochemical attributes (Kwon et al., 2000).

The present study was carried out to investigate the effects of $\mathrm{AlCl}_{3}$ on some biochemical parameters in rats either in absence or presence of irradiated ginseng in order to demonstrate the potential beneficial role of this medicinal plant against $\mathrm{AlCl}_{3}$ damage.

\section{Materials and Methods}

\section{Material}

$\mathrm{AlCl}_{3}$ was purchased from Sigma, chemical Company. Ginseng was purchased from an Egyptian local market (Harraz Co., Cairo, Egypt).

\section{Irradiation process}

Powder of ginseng was transferred into polyethylene bags and treated with $10 \mathrm{KGy}$ of gamma rays, using a ${ }^{60} \mathrm{Co}$ source at a dose rate of $4.75 \mathrm{KGy} / \mathrm{h}$ at the NCRRT, Cairo, Egypt.

Egypt. J. Rad. Sci. Applic., Vol. 24, No. 2 (2011) 
White albino male rats $(200 \pm 10 \mathrm{~g})$ were housed in standard plastic cages at an environmentally controlled room (constant temperature $25 \pm 2{ }^{\circ} \mathrm{C}$, with $12 \mathrm{~h}$ light/ dark cycle) during the experiment. They were fed a standard pellet diet and water ad libitum.

Four groups of rats each of 8 rats were used; they were treated as follows: Control group: Untreated rats, IGE group: Rats received orally $\gamma$-irradiated ginseng powder ( $400 \mathrm{mg} \mathrm{kg}^{-1}$ body wt daily) dissolved in water during the experiment which lasted for six weeks (Turan et al., 2010). AL group: Rats received orally by gavages $1 \mathrm{ml}$ of a solution containing $0.5 \mathrm{mg} \mathrm{kg}^{-1}$ body wt of $\mathrm{ALCL}_{3}$ in $\mathrm{H}_{2} \mathrm{O}$ per day for six weeks (Al-Hashem, 2009) and IGE + AL group: Rats received IGE $+\mathrm{ALCL}_{3}$ as described for group 2 and 3.

At the end of the experimental duration (six weeks), the animals were subjected to over night fasting before sacrifice. The rats were euthanized under general anaesthesia with diethyl ether. Blood samples were collected and centrifuged at $1,500 \times \mathrm{g}$ for $10 \mathrm{~min}$ to obtain serum.

The counts of red blood cells (RBCs) were counted by the haemocytometer method. The haemoglobin $(\mathrm{Hb})$ level was determined spectrophotometrical and the haematocrit $(\mathrm{Hct})$ volume was determined by the microhaemotocrit tube method. Serum transaminases (aspartate amino transferase; AST) and (alanine aminotransferase; ALT) activities were determined following the method of Reitman and Frankel (1957). Alkaline phosphatase (ALP) activity was measured according to Roy et al (1970). The activity of lactate dehydrogenase (LDH) was measured according to the methods of Moss and Handerson (1994). Follicle-stimulating hormone (FSH) and luteinizing hormone ( $\mathrm{LH})$ levels were estimated using a radioimmunoassay (RIA) kits (Diagnostic Product Corporation, Los Angeles, USA). Also, serum testosterone (T) level was determined using a test reagent kit based on a solid phase enzyme linked immunosorbent assay (Sanchez et al., 1998). Furthermore, thiobarbituric acid reactive substances (TBARS) concentration, (Yoshioka et al., 1979), reduced glutathione (GSH) content (Beutler et al., 1963), superoxide dismutase (SOD) (Minami and Yoshikawa, 1979) and catalase (CAT) (Johansson and Borg, 1988) activities were determined in liver and testes. Moreover, protein content (Lowry et al., 1951). 


\section{Statistical analysis}

Data are given as the mean \pm SE. One-way analysis of variances ANOVA (Steel and Torrie, 1980) was used to determine if the difference observed among various treatment groups was significant at $P<0.05$.

\section{Results}

The effect of $\mathrm{AlCl}_{3}$ and IGE on some haematological parameters of rats and the significance of differences among them are shown on Table 1. After six weeks of $\mathrm{AlCl}_{3}$ administration, there was a significant decrease in $\mathrm{RBCs}$ count, $\mathrm{Hb}$ and Hct percentage compared to the control. On the other hand, these parameters were significantly $(P<0.05)$ increased in IGE $+\mathrm{Al}$ treated group versus $\mathrm{AlCl}_{3}$ treated rats (Table 1). Significant $(P<0.05)$ increments in these haematological parameters were also observed when IGE utilized alone.

TABLE 1. Effect of IGE administration to $\mathrm{ALCL}_{3}$ intoxicated rats on some haematological parameters.

\begin{tabular}{|c|c|c|c|}
\hline Groups & RBCs $\left(10^{6} / \mathrm{mm}^{3}\right)$ & Hb $(\mathrm{g} / \mathrm{dl})$ & Het $(\%)$ \\
\hline Control & $9.28 \pm 0.45^{\mathbf{b}}$ & $12.25 \pm 0.35^{\mathbf{b}}$ & $43.50 \pm 0.29^{\mathbf{b}}$ \\
\hline IGE & $11.10 \pm 0.02^{\mathbf{a}}$ & $15.05 \pm 0.37^{\mathbf{a}}$ & $46.70 \pm 0.45^{\mathbf{a}}$ \\
\hline Al & $7.40 \pm 0.26^{\mathbf{c}}$ & $10.56 \pm 0.24^{\mathbf{c}}$ & $39.00 \pm 1.20^{\mathbf{c}}$ \\
\hline Al+ IGE & $9.18 \pm 0.27^{\mathbf{b}}$ & $12.82 \pm 0.10^{\mathbf{b}}$ & $42.94 \pm 0.54^{\mathbf{b}}$ \\
\hline
\end{tabular}

Data are expressed as mean \pm SE. of 8 rats per group. Values with different superscript in the same columns are significantly different at $P \leq 0.05$.

Significant $(P<0.05)$ rise was exhibited in the activity of ALT, AST, ALP and $\mathrm{LDH}$ in serum of $\mathrm{AlCl}_{3}$ treated rats relative to control animals. The incorporation of IGE along with $\mathrm{AlCl}_{3}$ significantly $(P<0.05)$ reduced the release of these diagnostic hepatic marker enzymes (Table 2).

TABLE 2. Effect of IGE administration on serum liver markers of $\mathrm{ALCL}_{3^{-}}$ intoxicated rats.

\begin{tabular}{|c|c|c|c|c|}
\hline Groups & ALT $(\mathrm{U} / \mathrm{ml})$ & AST $(\mathrm{U} / \mathrm{ml})$ & ALP $(\mathrm{U} / \mathrm{l})$ & $\mathbf{L D H}(\mathrm{U} / \mathrm{l})$ \\
\hline Control & $36.86 \pm 1.73^{\mathbf{c}}$ & $81.27 \pm 2.16^{\mathbf{c}}$ & $77.46 \pm 3.05^{\mathbf{c}}$ & $193.44 \pm 4.25^{\mathbf{c}}$ \\
\hline IGE $^{\mathbf{c}}$ & $36.09 \pm 1.56^{\mathbf{c}}$ & $84.08 \pm 1.93^{\mathbf{c}}$ & $76.18 \pm 1.63^{\mathbf{c}}$ & $182.16 \pm 5.78^{\mathbf{d}}$ \\
\hline Al & $49.92 \pm 1.32^{\mathbf{a}}$ & $149.45 \pm 4.86^{\mathbf{a}}$ & $131.27 \pm 2.72^{\mathbf{a}}$ & $288.97 \pm 6.13^{\mathbf{a}}$ \\
\hline Al+ IGE & $40.69 \pm 1.28^{\mathbf{b}}$ & $97.37 \pm 2.87^{\mathbf{b}}$ & $86.34 \pm 1.84^{\mathbf{b}}$ & $205.08 \pm 4.76^{\mathbf{b}}$ \\
\hline
\end{tabular}

Legends as in Table 1 .

As seen in Table 3, $\mathrm{AlCl}_{3}$ supplementation to rats produced a significant $(P<0.05)$ decline in serum $\mathrm{T}, \mathrm{LH}$ and $\mathrm{FSH}$ concentration than control rats. While, the administration of IGE with $\mathrm{AlCl}_{3}$ for the same treatment period maintained the level of these sex hormones to approximate the control level.

Egypt. J. Rad. Sci. Applic., Vol. 24, No. 2 (2011) 
TABLE 3. Effect of IGE administration on serum level of T, $\mathrm{LH}$ and $\mathrm{FSH}$ in $\mathrm{AlCl}_{3}$ intoxicated rats.

\begin{tabular}{|c|c|c|c|}
\hline Groups & T $(\mathrm{nmol} / \mathrm{l})$ & LH $(\mathrm{U} / 1)$ & FSH $(\mathrm{U} / \mathrm{l})$ \\
\hline Control & $4.73 \pm 0.12^{\mathbf{a}}$ & $0.88 \pm 0.14^{\mathbf{a}}$ & $0.79 \pm 0.05^{\mathbf{a}}$ \\
\hline IGE & $4.87 \pm 0.15^{\mathbf{a}}$ & $0.86 \pm 0.03^{\mathbf{a}}$ & $0.76 \pm 0.06^{\mathbf{a}}$ \\
\hline Al & $2.52 \pm 0.11^{\mathbf{b}}$ & $0.51 \pm 0.02^{\mathbf{c}}$ & $0.61 \pm 0.06^{\mathbf{b}}$ \\
\hline Al+ IGE & $4.67 \pm 0.13^{\mathbf{a}}$ & $0.75 \pm 0.02^{\mathbf{b}}$ & $0.71 \pm 0.04^{\mathbf{a b}}$ \\
\hline
\end{tabular}

Legends as in Table 1

As a consequence of exposure of rodents to $\mathrm{AlCl}_{3}$, it could be noticed that there was a significant $(P<0.05)$ elevation in the concentration of hepatic and testicular TBARS accompanied with a depression in GSH content in comparison with control rats. Concomitant oral administration of IGE and $\mathrm{AlCl}_{3}$ restored the TBARS and GSH content near the control levels (Table 4).

TABLE 4. Effect of IGE administration on the tissues TBARS and GSH levels in rats exposed to $\mathrm{ALCL}_{3}$.

\begin{tabular}{|c|c|c|c|c|}
\hline \multirow{2}{*}{ Group } & \multicolumn{2}{|c|}{ TBARS $(\mathrm{n}$ mol/g tissue) } & \multicolumn{2}{c|}{ GSH $(\mathrm{mg} / \mathrm{g}$ tissue) } \\
\cline { 2 - 5 } & Liver & Testes & Liver & Testes \\
\hline Control & $159.28 \pm 2.62^{\mathrm{c}}$ & $137.54 \pm 7.03^{\mathrm{c}}$ & $57.38 \pm 1.44^{\mathrm{a}}$ & $27.11 \pm 2.29^{\mathrm{a}}$ \\
\hline IGE & $153.31 \pm 4.92^{\mathrm{c}}$ & $102.49 \pm 3.97^{\mathrm{d}}$ & $58.40 \pm 2.59^{\mathrm{a}}$ & $27.24 \pm 1.5^{\mathrm{a}}$ \\
\hline Al & $221.25 \pm 5.98^{\mathrm{a}}$ & $198.26 \pm 9.24^{\mathrm{a}}$ & $26.52 \pm 2.87^{\mathrm{c}}$ & $18.92 \pm 1.13^{\mathrm{c}}$ \\
\hline Al + IGE & $176.08 \pm 5.84^{\mathrm{b}}$ & $161.10 \pm 4.65^{\mathrm{b}}$ & $50.25 \pm 2.1^{\mathrm{b}}$ & $23.84 \pm 1.12^{\mathrm{b}}$ \\
\hline
\end{tabular}

Legends as in Table 1.

SOD and CAT activity in the rat's liver and testes were significantly $(P<0.05)$ diminished in the $\mathrm{Al}$ group concerning control rats. However, feeding rats IGE alleviated the effects of $\mathrm{AlCl}_{3}$ and resulted in a significant $(P<0.05)$ increase in the antioxidant activity of these two enzymes when compared to Al.

TABLE 5. Effect of IGE administration to $\mathrm{ALCL}_{3}$ intoxicated rats on SOD and CAT activity of liver and testes.

\begin{tabular}{|c|c|c|c|c|}
\hline \multirow{2}{*}{ Group } & \multicolumn{2}{|c|}{ SOD (U/ mg protein) } & \multicolumn{2}{c|}{ CAT (U/ mg protein) } \\
\cline { 2 - 5 } & Liver & Testes & Liver & Testes \\
\hline Control & $51.19 \pm 3.37^{\mathrm{a}}$ & $19.66 \pm 1.44^{\mathrm{a}}$ & $15.81 \pm 0.27^{\mathrm{a}}$ & $11.88 \pm 1.2^{\mathrm{a}}$ \\
\hline IGE & $52.12 \pm 1.64^{\mathrm{a}}$ & $20.79 \pm 0.86^{\mathrm{a}}$ & $16.07 \pm 0.11^{\mathrm{a}}$ & $12.14 \pm 0.83^{\mathrm{a}}$ \\
\hline Al & $26.04 \pm 1.62^{\mathrm{b}}$ & $13.83 \pm 0.76^{\mathrm{c}}$ & $10.38 \pm 0.13^{\mathrm{c}}$ & $8.97 \pm 0.86^{\mathrm{c}}$ \\
\hline Al + IGE & $48.88 \pm 3.92^{\mathrm{a}}$ & $17.65 \pm 1.27^{\mathrm{b}}$ & $13.74 \pm 0.34^{\mathrm{b}}$ & $10.61 \pm 0.54^{\mathrm{b}}$ \\
\hline
\end{tabular}

Legends as in Table 1.

\section{Discussion}

The present study was undertaken to determine whether IGE can prevent or reduce $\mathrm{Al}$-induced oxidative stress in rats. AL toxicity may be mediated by

Egypt. J. Rad. Sci. Applic., Vol. 24, No. 2 (2011) 
free radical generation and alterations in antioxidant enzymes in vivo and in vitro (Tabaldi et al., 2009). The significant $(P<0.05)$ decreases in $\mathrm{Hb}$, RBCs and Hct among AL-treated rats corroborate the findings of Abdel Aziz and Zabut (2011). The reduction in $\mathrm{Hb}$ content might be due to increased rate of destruction or reduction in the rate of formation of RBCs. This intepretation was supported by the low levels of RBCs in the treated group. Vittori et al. (2002) have reported that AL may disturb erythropoiesis through combined effects on mature erythrocytes and cellular metabolism in late erythroid progenitors. Reductions in Hct, RBCs and $\mathrm{Hb}$ might be attributed to hyperactivity of bone marrow, leading to production of RBCs with impaired integrity that easily destroyed in the circulation (Karmakar et al., 2000). The decline in $\mathrm{Hb}$ could be not only due to decrease in RBCs count but also to impaired biosynthesis of haeme in the bone marrow (Karmakar et al., 2000).

As seen here, co administration of IGE with AL showed beneficial haematological effects. The RBCs, Hb and Hct values were largely restored. In harmony with these observations, it was deduced that ginseng improved the haematological parameters of rats (Karadeniz and Altintas, 2008). This protective effect of ginseng against AL-induced toxicity can be ascribed mainly to its antioxidant ability or its stimulatory effects on erythropoiesis (Scaglione et al., 1990). Moreover, panax ginseng treatment may stimulate the activity of the bone marrow stem cells and consequently strengthen systemic and particularly immune cellular defences of the organism (Jensen et al., 2000).

The activities of AST, ALT, ALP and LDH in serum were increased after toxicant administration. These findings are well correlated with those of Abdel Aziz and Zabut (2011) and Al-Hashem (2009). It is of interest to mention that in animals treated with toxicants, the serum levels of these enzymes elevated after liver damage, and thus alterations in liver function, because of increased membrane permeability or due to liver cell necrosis and cytosol leakage into the serum (Ozer et al., 2008). The data of the current study revealed that the incorporation of IGE inhibited the rise in serum level of these enzymes. This could indicate improvement of liver function and protection from the toxicity of AL. These results are in agreement with the study of Young et al. (2011) who mentioned that Korean red ginseng (KRG) pre-treatment clearly ameliorated the increased levels of ALT and AST indicating that KRG may have protective effects against hepatotoxicity induced by Aflatoxin B1. As well, Egypt. J. Rad. Sci. Applic., Vol. 24, No. 2 (2011) 
Hye et al, (2011) postulated that KRG treatment prior to administration of ethanol $(\mathrm{EtOH})$ to rats decreased the EtOH-induced increase in serum AST, ALT and LDH.

The obtained findings proved that $\mathrm{AlCl}_{3}$ intoxication to rats significantly $(P<0.05)$ reduced serum T, FSH and LH levels. These data go in line with those of Shahraki and Palan (2006). Those authors documented that AL injection in rats has an adverse effect on some sex hormones. As well as, Wang et al. (2012) sustained that $\mathrm{AlCl}_{3}$ administrated orally to rats significantly diminished the levels of T, FSH, and LH. In this regard, IGE along with $\mathrm{AlCl}_{3}$ produced a significant $(P<0.05)$ enhancement in T and FSH levels. The LH level was also improved. These outcomes are consistent with the earlier report of (Fahim et al., 1982). Panax ginseng is an old and well-known plant that is used to prevent sexual dysfunction. It was suggested that the antioxidant and organ protective actions of ginseng are associated with enhanced nitric oxide (NO) synthesis in the endothelium of the lung, heart, kidney and corpus cavernosum (Chen and Lee, 1995). Enhanced NO synthesis causes vasodilatation and might be responsible for the aphrodisiac property of ginseng (Murphy and Lee, 2002). Treatment with ginseng has been shown to significantly alter the activity of hypothalamic catecholamines involved in the facilitation of hormone secretion (Murphy and Lee, 2002). They also indicated that ginseng improves the reduced feedback from the testes to the pituitary gland, resulting in an increase in the amount of testosterone secreted from $\mathrm{LH}$ stimulated Leydig cells.

Chronic exposure to $\mathrm{AlCl}_{3}$ causes a mineral imbalance in which $\mathrm{AL}$ ions replace iron and magnesium ions resulting in a reduction of $\mathrm{Fe} 2+$ binding to ferritin (Ward et al., 2001). Free iron ions released from biological complexes by AL can catalyze hydrogen peroxide, generating hydroxyl radicals through Fenton's reaction (Ward et al., 2001). These radicals are able to initiate LPO and cellular damage (Yousef et al., 2007). Also, AL has been reported to promote non-iron-induced LPO (Ward et al., 2001). Experimental data exhibited that toxicant supplementation to rats significantly $(P<0.05)$ increased the LPO in liver and testes which was evident by the increased production of TBARS. In agreement with these issues, Shrivastava (2011) and Al-Hashem (2009) declared significant increase in TBARS in the kidney, liver, brain and 
testes of rats after intoxication by AL salts. The enhanced TBARS suggests participation of free-radical induced oxidative cell injury in mediating the toxicity of Al. High LPO is, at least in part, due to an inhibition or alteration in the activity of non-enzymatic and enzymatic components of the oxidative system.

GSH, an essential component of oxidative system, serves as a cofactor for glutathione transferase, which helps to remove certain drugs and chemicals, as well as reactive molecules, from the cells (Wu and Cederbaum, 2003). Moreover, GSH can directly detoxify hydroxyl radicals and is critical for mediating other key activities in the cell. Al caused significant $(P<0.05)$ decrease in the GSH content in liver and testes. Metals as cadmium, cisplatin, lead and mercury induced oxidative stress by depleting the major intracellular antioxidant, glutathione in liver, kidney and brain (Afifi, 2010). Al might affect GSH synthesis by decreasing the activity of glutathione-synthase thus leading to a reduced GSH levels (Orihuela et al., 2005).

IGE plus $\mathrm{AlCl}_{3}$ produced significant $(P<0.05)$ decrease in TBARS accompanied by significant $(P<0.05)$ increase in GSH content. In accordance with these observations Zhang et al. (2008) concluded that ginseng total saponin was shown to protect against oxidative stress induced by cyclophosphamide in mouse bone marrow cells and peripheral lymphocytes. Also, Gum et al. (2007) reported that ginseng water extract reversed the reduction of GSH and GST activity induced by benzo [a] pyrene in rats.

The enzymatic antioxidant defence system, which includes SODs and CATs, helps protect cells from oxidative injuries. SOD catalyzes the rapid removal of superoxide radicals, generating $\mathrm{H}_{2} \mathrm{O}_{2}$, which is eliminated by catalases ( $\mathrm{Wu}$ and Cederbaum, 2003). In the present work, $\mathrm{AlCl}_{3}$ induced free radicals and may inhibit the enzymes involved in antioxidant defense: SOD and CAT. A significant drop was observed in the serum antioxidant enzymes of treated rats. This coincides with Nehru and Anand (2005) who stated a significant reduction in the activities of SOD and CAT in the brain after AL treatment. The decline in both enzyme activities could be due to a reduced synthesis of these enzymes proteins because of higher intracellular concentrations of AL or due to accumulation of free radicals (Nehru and Anand, 2005).

Egypt. J. Rad. Sci. Applic., Vol. 24, No. 2 (2011) 
Significant $(P<0.05)$ rise in the two antioxidant enzymes in the liver and testes of treated rats were observed in response to combined treatment of IGE and $\mathrm{AlCl}_{3}$. Kim et al. (2005) ascertain that ginseng extract produced elevation of CAT and SOD activity and decreased malondialdehyde levels in sedentary male patients. Recently, Young et al. (2011) corroborated these events. Ginseng root extracts exhibit both lipid-soluble and water-soluble antioxidant activity ex vivo, and that this antioxidant action occurs both directly through free radical scavenging and indirectly through up regulation of antioxidant enzymes (Kim et al., 2002). Ginsenosides have been associated with the up regulation of both SOD and CAT enzymes at the level of gene expression and transcription (Kim and Park, 2003).

Our results demonstrate that $\mathrm{AlCL}_{3}$ alters haematological, biochemical and hormonal parameters and induce oxidative stress. Consequently, attention should be paid to the sources of AL in food, water and medical drugs. Ginseng ingestion along with $\mathrm{AlCL}_{3}$ exposure minimized $\mathrm{Al}$-associated hazards due to its antioxidant and free radical scavenging properties. Therefore, ginseng could be beneficial for reducing AL toxicity.

\section{References}

Abbasali, K. M., Zhila, T. and Farshad, N. (2005) Developmental toxicity of aluminum from high doses of $\mathrm{AlCl} 3$ in mice. J. Appl. Res., 5, 575.

Abdel Aziz, I. S. and Zabut, M. B. (2011) Determination of blood indices of albino rats treated with aluminum chloride and investigation of antioxidant effects of vitamin $\mathrm{E}$ and C. Egypt. J. Biol., 13, 1.

Afifi, M. E. (2010) Effect of camel's milk on cisplatin-induced nephrotoxicity in Swiss Albino Mice. Am. J. Biochem. Biotechnol., 6, 141.

Al-Hashem, F. H. (2009) Camel's milk alleviates oxidative stress and lipid peroxidation induced by chronic aluminum chloride exposure in rat's testes. Am. J. Appl. Sci., 6, 1868.

Beutler, E., Duron, O. and Kelly, B. M. (1963) Improved method for the determination of blood glutathion. J. Lab. Clin. Med., 61, 882.

Campbell, A. (2002) The potential role of aluminum in Alzheimer's disease. Nephrol. Dial. Transplant., 17, 17.

Chen, X. and Lee, T. J. (1995) Ginsenosides-induced nitric oxide mediated relaxation of the rabbit corpus cavernosum. Br. J. Pharmacol., 115, 15.

Cho, H. O., Byun, M. W., Kang, I. J., Youk, H. S. and Kwon, J. H. (1994) Improvement of hygienic quality of white ginseng powders by gamma irradiation. Radioisotopes, 43, 750 .

Egypt. J. Rad. Sci. Applic., Vol. 24, No. 2 (2011) 
Fahim, M., Fahim, Z. Harman, J., Clevenger, T., Mullins, W. and Hafez, E. (1982) Effect of Panax ginseng on testosterone level and prostate in male rats. Arch. Androl., 8, 261.

Gum, S., Jo, S., Ahn, S., Kim, S., Kim, J., Shin, H. and Cho, M. (2007) The potent protective effect of wild ginseng (Panax ginseng C.A. Meyer) against benzo (alpha) pyrene-induced toxicity through metabolic regulation of CYP1A1 and GSTs. J. Ethnopharmacol., 112, 568.

Gupta, V. B., Anitha, S., Hegde, M., Zecca, L., Garruto R., Ravid R., and Shankar, S. K. (2005) Aluminum in Alzheimer's disease: Are we still at a crossroad? Life Sci., 62, 143.

Hye, M., Shang, J., Hyeon, K., Gi, B., Sung, Z., Jin, S., and Hyung, S. (2011) Korean red ginseng prevents ethanol-induced hepatotoxicity in isolated perfused rat liver. Korean J. Vet. Res., 51, 159.

Jensen, G., Ginsberg, D., Huerta, P., Citton, M. and Drapeau, M. (2000) Consumption of Aphanizomenon flos-aquae has rapid effects on the circulation and function of immune cells in humans. J. Am. Nutraceutical Assoc., 2, 50.

Johansson, L. and Borg, L. (1988) A spectrophotometric method for determination of CAT activity in small tissue samples. Anal. Biochem., 174, 331.

Karadeniz, A. and Altintas, L. (2008) Effects of Panax ginsing on fluoride-induced haematological pattern changes in mice. Fluoride, 41, 67.

Karmakar, R., Bhattacharya, R. and Chatterjee, M. (2000) Biochemical, haematological and histopathological study in relation to time-related cadmium-induced hepatotoxicity in mice. Biometals, 13, 231.

Kennedy, D., Scholey, A., Drewery, L., Marsh, V., Moore, B. and Ashton, H. (2003) Electroencephalograph effects of single doses of Ginko biloba and Panax ginseng in healthy young volunteers. Pharmacol. Biochem. Behav., 75, 701.

Kim, S. H. and Park, K. S. (2003) Effects of Panax ginseng extract on lipid metabolism in humans. Pharmacol. Res., 48, 511.

Kim, S., Park, K. Chang, M. and Sung, J. (2005) Effects of Panax ginseng extract on exercise-induced oxidative stress. J. Sports Med. Phys. Fitness, 45, 178.

Kim, Y. K., Guo, Q. and Packer, L. (2002) Free radical scavenging activity of red ginseng aqueous extracts. Toxicology, 172, 149.

Kwon, J. H., Byun, M. W., Kim, K. S. and Kang, I. J. (2000) Comparative effects of gamma irradiation and phosphine fumigation on the quality of white ginseng. Radiat. Phys. Chem., 57, 309.

Lowry, O. H., Roseprough, N. J., Farr, A. I. and Randall, R. J. (1951) Protein measurement with Folin Phenol reagent. J. Biol. Chem., 193, 265.

Minami, M. and Yoshikawa, H. (1979) A simplified assay method of superoxide dismutase. Clin. Chem. Acta, 92, 337.

Moss, D. and Handerson, A. (1994) Lactate dehydrogenase. 2nd Ed., Textbook of clinical chemistry, chapter 20, Enzymes, pp. 812 - 818.

Murphy, L. L. and Lee, T. J. (2002) Ginseng, Sex Behavior, and Nitric Oxide. Annals N. Y. Acad. Sci., 962, 372.

Egypt. J. Rad. Sci. Applic., Vol. 24, No. 2 (2011) 
Nehru, B. and Anand, P. (2005) Oxidative damage following chronic aluminum exposure in adult and pup rat brains. J. Trace Elem. Med. Biol., 19, 203.

Orihuela, D., Meichtry, V., Pregi, N. and Pizarro, M. (2005) Short-term oral exposure to aluminum decreases glutathione intestinal levels and changes enzyme activities involved in its metabolism. J. Inorg. Biochem., 99, 1871.

Osinska, E., Kanoniuk, D. and Kusiak, A. (2004) Aluminum hemotoxicity mechanisms. Ann. Univ. Mariae Curie Sklodowska Med., 59, 411.

Ozer, J., Ratner, M., Shaw, M., Bailey, W. and Schomaker, S. (2008) The current state of serum biomarkers of hepatotoxicity. Toxicology, 245, 194.

Reitman, S. and Frankel, S. (1957) A calorimetric method for determination of serum transaminases. Am. J. Clin. Path., 28, 56.

Roberts, N., Zhu, H., Kim, J., Shin, H. and Choi, S. (2002) Further studies on the interrelationship of aluminum and silicon in patients receiving aluminum hydroxide therapy for dyspepsia and factors that relate to the solubilization of aluminum. J. Trace Elem. Exp. Med., 15, 9.

Roy, A., Brower, M. and Hayden, J. (1970) Sodium thymolphthalein monophosphate. A new acid phosphatase substrate with greater specificity for the prostate enzyme in serum. Clin. Chem., 17, 1093.

Sanchez, C., Mauri, M., Alfayate, R., Miralles, C. and Soria, F. (1998) Elecsys Testosterone Assay Evaluated. Clin. Chem., 44, 1744.

Scaglione, F., Ferrara, F., Dugnani, S., Falchi, M., Santoro, G. and Fraschini, F. (1990) Immunomodulatory effects of two extracts of Panax ginseng C.A. Meyer. Drugs Exp. Clin. Res., 16, 537.

Shahraki, M. R. and Palan, M. J. (2006) Effect of aluminium on testosterone hormones in male rat. J. Med. Sci., 6, 296.

Shao, Z., Xie, J., Hoek, T., Mehendale, S., Aung, H., Li, C., Qin, Y., Schumacker, P., Becker, L. and Yuan, C. (2004) Antioxidant effects of American ginseng berry extract in cardio-myocytes exposed to acute oxidant stress. Biochem. Biophys. Acta, 1670, 165.

Sharma, P. and Mishra, K. (2006) Amelioration of fumonisin B1 hepatotoxicity in mice by depletion of T cells with anti-Thy-1.2. Reprod. Toxicol., 21, 313.

Shrivastava, S. (2011) S-Allyl- Cysteines Reduce Amelioration of Aluminum Induced Toxicity in Rats. Am. J. Bioch.. Biotechnol., 7, 74.

Steel, R. G. and Torrie, J. A. (1980) Principles and procedures of statistics, 2nd ed., USA: McGraw- Hill, pp. 183-193.

Tabaldi, L., Cargnelutti, D., Goncalves, J., Pereira, L. Castro, G. and Maldaner, J. (2009) Oxidative stress is an early symptom triggered by aluminum in Alsensitive potato plantlets. Chemosphere, 76, 1402.

Turan, K., Mecit, Y., Ibrahim, H. Y. and Sema, U. (2010) Effects of extract of green tea and ginseng on bancreatic beta cells and levels of serum glucose, insulin, cholesterol and triglycerides in rats with experimentally streptozotozin-induced diabetes: A histochemical and immunohistochemical study. J. Anim. Vet. Adv., 9, 102 . 
Vittori, D., Garbossa, G., Lafourcade, C., Perez, G. and Nesse, A. (2002) Human erythroid cells are affected by aluminium. Alteration of membrane band 3 protein. Biochim. Biophys. Acta 1558, 142.

Wang, N.,_She, Y.,_Zhu, Y.,_Zhao, H., Shao, B.,_Sun, H.,_Hu, C. and_Li, Y. (2012) Effects of subchronic aluminum exposure on the reproductive function in female rats. Biol. Trace Element Res., 145, 382.

Ward, R. J., Zhang, Y. and Crichton, R. R. (2001) Aluminum toxicity and iron homeostasis. J. Inorg. Biochem., 87, 9.

Wu, D. and Cederbaum, A. (2003) Alcohol, oxidative stress and free radical damage. Alcohol Res. Health, 27, 277.

Xie, J. T., Mehendale, S. R., Wang, A., Han, A. H., Wu, J. A., Osinski, J. and Yuan, C. S. (2004) American ginseng leaf: ginsenoside analysis and hypoglycemic activity. Pharmacol. Res., 49, 113.

Yoshioka, T., Kawada, K., Shimada, T. and More, M. (1979) Lipid peroxidation in maternal and cord blood and protective mechanism aganist activated oxygen toxicity in the blood. Am. J. Obstet. Gynecol., 135, 372.

Young, S. K., Yong, H. K., Jung, R. N., Eun, S. C., Jong, H. P. and Hwa, Y. S. (2011) Protective Effect of Korean Red Ginseng against Aflatoxin B1-Induced Hepatotoxicity in Rat. J. Ginseng Res., 35, 243.

Yousef, M., Kamel, K., El-Guendi, M. and El-Demerdash, F. (2007) An in vitro study on reproductive toxicity of aluminum chloride on rabbit sperm: the protective role of some antioxidants. Toxicology, 239, 213.

Zhang, Q., Wu, C., Duan, L. and Yang, J. (2008) Protective effects of saponins from stem and leaf of P. ginseng against cyclophosphamide-induced genotoxicity and apoptosis in mouse bone marrow cells and peripheral lymphocyte cells. Food Chem. Toxicol., 46, 293.

(Received: 14/06/2012;

accepted: 17/07/2012)

Egypt. J. Rad. Sci. Applic., Vol. 24, No. 2 (2011) 


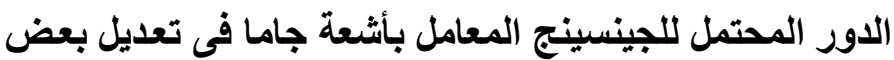

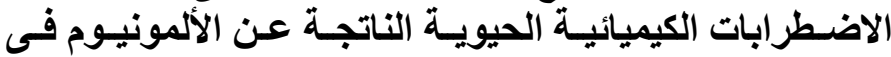

$$
\begin{aligned}
& \text { الجرذان } \\
& \text { محد فوزى صلاح الدين فرج ، و رفعت جلال حمزة }
\end{aligned}
$$

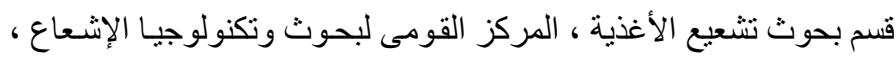

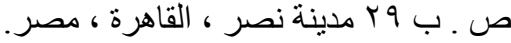

\footnotetext{
لقد حظي التأثير السام للألمونيوم فى الإنسان و الحيوان على قدر كبير من

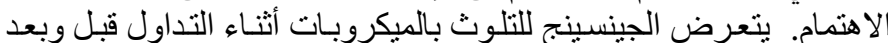

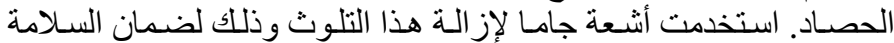

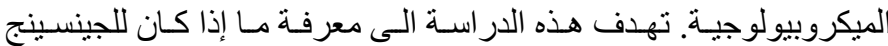

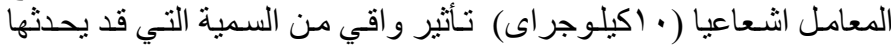

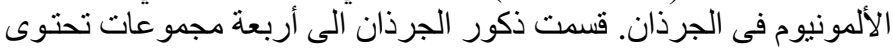

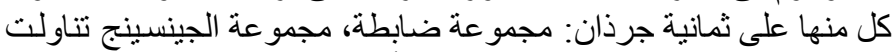

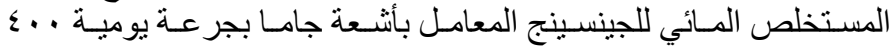

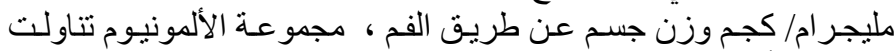

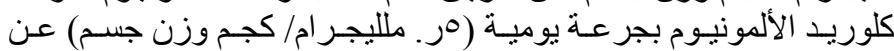

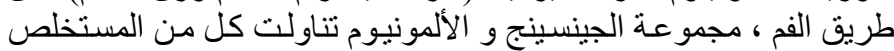

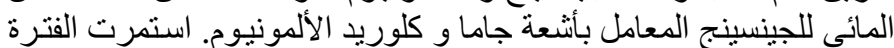

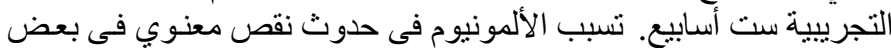

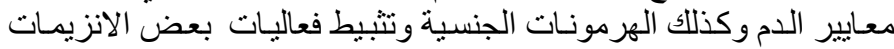

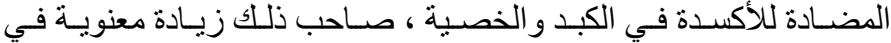

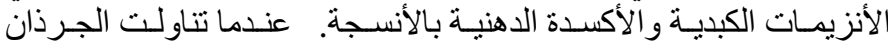

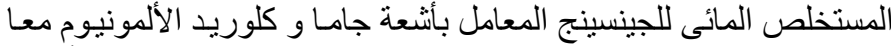

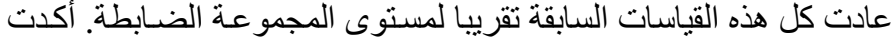

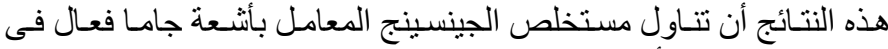

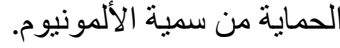

